\title{
SCANNING ELECTRON MICROSCOPE DOCUMENTATION OF THE LOST HOLOTYPES OF MORNOD, 1949: THALMANNINELLA REICHELI AND ROTALIPORA MONTSALVENSIS
}

\author{
Michele Caron and Silvia Spezzaferri ${ }^{1}$ \\ University of Fribourg, Department of Geosciences, Geology and Paleontology, Chemin du Musée 6, 1700 Fribourg, Switzerland
}

ABSTRACT

The species Globotruncana (Rotalipora) reicheli and Gobotruncana (Rotalipora) montsalvensis, were established in 1949 by Mornod. The two holotypes were figured only by drawings and the specimens were never made publicly available. Since their first description, these two species have acquired great importance as biostratigraphic markers. However, holotypes had been considered as lost and neotypes were established and described.

Recently, these holotypes were discovered. We present here for the first time Scanning Electron Microscope images of the holotypes and compare them with the original drawings and neotypes to highlight possible similarities and differences. Generic assignment is made following a recent emendation for the polyphyletic group of rotaliporids, with the generic attribution as follows: Thalmanninella reicheli (Mornod) and Rotalipora montsalvensis Mornod.

\section{INTRODUCTION}

\section{IMPORTANCE OF THALMANNINELLA REICHELI AND ROTALIPORA MONTSALVENSIS}

Since they were first described, Thalmanninella reicheli and Rotalipora montsalvensis have acquired increasing importance as worldwide stratigraphic marker fossils for the Cenomanian at lower-to-middle latitudes. In particular, their temporal distribution, which as been cited as $\sim 200 \mathrm{Ka}$ and $2 \mathrm{Ma}$, respectively according to Premoli Silva and Verga (2004) or $500 \mathrm{ka}$ and 3 Ma respectively, according to Gonzalez-Donoso and others (in press), establishes their importance for biostratigraphy. Thalmanninella reicheli is also the marker fossil for the Th. reicheli Zone.

When these species were established (Mornod, 1949), the author provided only drawings of the holotypes since the electron microscope was not in use at the time. Many scientists have attempted to obtain access to the holotypes; but the author always turned down the requests.

The absence of SEM images of the holotypes and the stratigraphic importance of the two species, led to the establishment of neotypes. Caron (1976) provided excellent SEM images of the type material (topotypes from the type locality of Montsalvens area), but provided only drawings of the neotypes, because at the time there was no guarantee for the safety of the specimens after SEM imaging.

Recently, L. Mornod passed away and his wife donated his library and samples to the Department of Geosciences, Geology and Paleontology of the University of Fribourg, where he was formerly a student. Such material included a box with the collection of foraminifers from the

${ }^{1}$ E-mail: silvia.spezzaferri@unifr.ch
Montsalvens area and the holotypes of Globotruncana (Rotalipora) reicheli and Globotruncana (Rotalipora) monsalvensis in the original slides.

Presently, the Mesozoic Planktonic Foraminifers Working Group (of which the two authors are members), chaired by $\mathrm{B}$. Huber of the Smithsonian Institution, is engaged in the compilation of an on-line taxonomic dictionary of Mesozoic planktonic foraminifers in the framework of the CHRONOS initiative (US-NSF Project; http://www. chronos.org). Following the recommendation of the working group during its second meeting in Fribourg, Switzerland (June 2005), Gonzalez-Donoso and others (in press) proposed a redefinition of the polyphyletic group of rotaliporids. This revision includes the revision and redescription of the genera Pseudothalmanninella, Thalmanninella and Rotalipora based on a combination of new and old criteria. Globotruncana (Rotalipora) montsalvensis is assigned to the genus Rotalipora and Globotruncana (Rotalipora) reicheli is assigned to the genus Thalmanninella. This new classification is based on lineage affinities more than on morphological differences, making the documentation and availability of type specimens an essential requirement for its correct application.

We present here for the first time, the SEM images of these holotypes and their neotypes. We also compare them with the original drawings of Mornod (1949) and with the neotype's drawings of Caron (1976).

\section{THE TYPE LOCALITY}

The two species were both described from a site located along the Rio des Covayes in the Massif du Montsalvens in the Fribourg Prealpes. Being very small, the Rio des Covayes is, unfortunately, not reported on the topographic map of Gruyères (1:25000, map number 1225). The type locality of these species is $\sim 1 \mathrm{~km}$ north of Cerniat as described by Mornod (1949).

The site has three outcrops that are very closed to each other: Outcrop I at about $1075 \mathrm{~m}$, Outcrop II at about $1000 \mathrm{~m}$ and Outcrop III between 975 and $985 \mathrm{~m}$ of altitude. The type level of Thalmanninella reicheli is located at Outcrop III, level 18 and the type level of Rotalipora montsalvensis at Outcrop II, level 13 (Mornod, 1949).

The Upper Cretaceous sedimentary succession represents the uppermost part of the Jurassic-Cretaceous Series of the Ultrahelvetic Nappe in the Montsalvens area. Cenomanian sediments consist of dark gray, clayey chalks with greenishblackish intercalations. Turonian sediments consist of whitish and massive chalks with clay intercalations (Caron, 1976). 


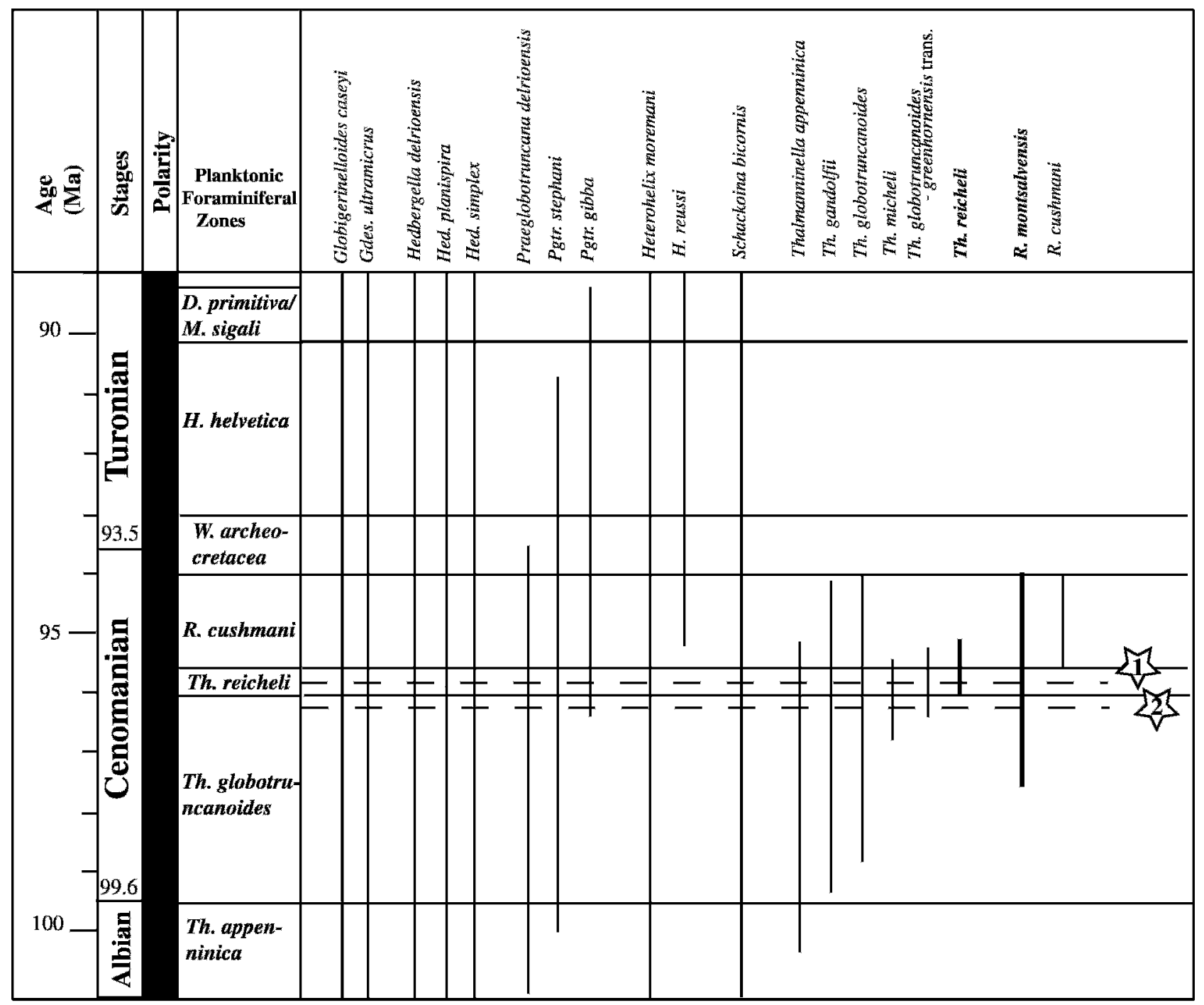

1- Stratigraphic position of the type locality of Th. reicheli (Mornod)

2 -Stratigraphic position of the type locality of $R$. montsalvensis Mornod

FIGURE 1. Distribution of planktonic foraminifera in the type locality of $R$. montsalvensis and Th. reicheli, Montsalvens area, Canton Fribourg, Switzerland. Star 1 and Star 2 mark the stratigraphic positions of Th. reicheli and $R$. montsalvensis in the type section, respectively. Time scale from Ogg and others (2004).

\section{METHODS}

SEM documentation of the holotypes of Rotalipora montsalvensis and Thalmanninella reicheli was obtained using the standard coating techniques for SEM samples preparation. The neotypes are deposited in the Natural History Museum of Basel. Since we did not have permission to coat the neotypes with gold, and the digital images did not show sufficient resolution, we applied an alternative methodology to obtain the SEM images.

The following procedure was applied: specimens were placed on standard glue tape on a SEM sample holder, which had been coated with an annular layer of silver paint to assure good conductivity. The neotypes were then placed in a scanning electron microscope (SEM - FEI XL30 Sirion FEG) and observed with a beam of $3 \mathrm{KV}$ and a Spot 2, which are the minimum values that give reasonably good images without damaging the samples with the electron flux.

\section{SYSTEMATIC TAXONOMY}

Thalmanninella reicheli and Rotalipora montsalvensis are very well described and documented species; therefore the detailed diagnosis of the holotypes is here omitted. However, based on the SEM images of holotypes and neotypes in comparison with drawings we can now stabilize the main criteria for the identification of the two species.

\section{Thalmanninella reicheli (Mornod, 1949)}

Plate 1, figures $1-4$

Type reference: Globotruncana (Rotalipora) reicheli Mornod, 1949 , p. 583-584, fig. 5 (IVa-c); present article, pl. 1, figs. 1a-c, 2a-c.

Neotype: Rotalipora reicheli Mornod; Caron, 1976, p. 330-331, textfigs. 2a-c.

Topotypes: Rotalipora reicheli Mornod; Caron, 1976, pl. II, figs.1-5.

This species is readily recognizable by its distinct planoconvex, more or less cylindrical profile. The spiral side is flat to slightly concave (easily visible on the holotype), the umbilical side is highly convex. Mornod's drawings of the holotype (Plate 1, figs. 2a-c) are consistent with SEM images (Plate 1, figs. 1a-c). In particular, the SEM images of the holotype and neotype (Plate 1, figs. 3a-c) have the same umbilical 


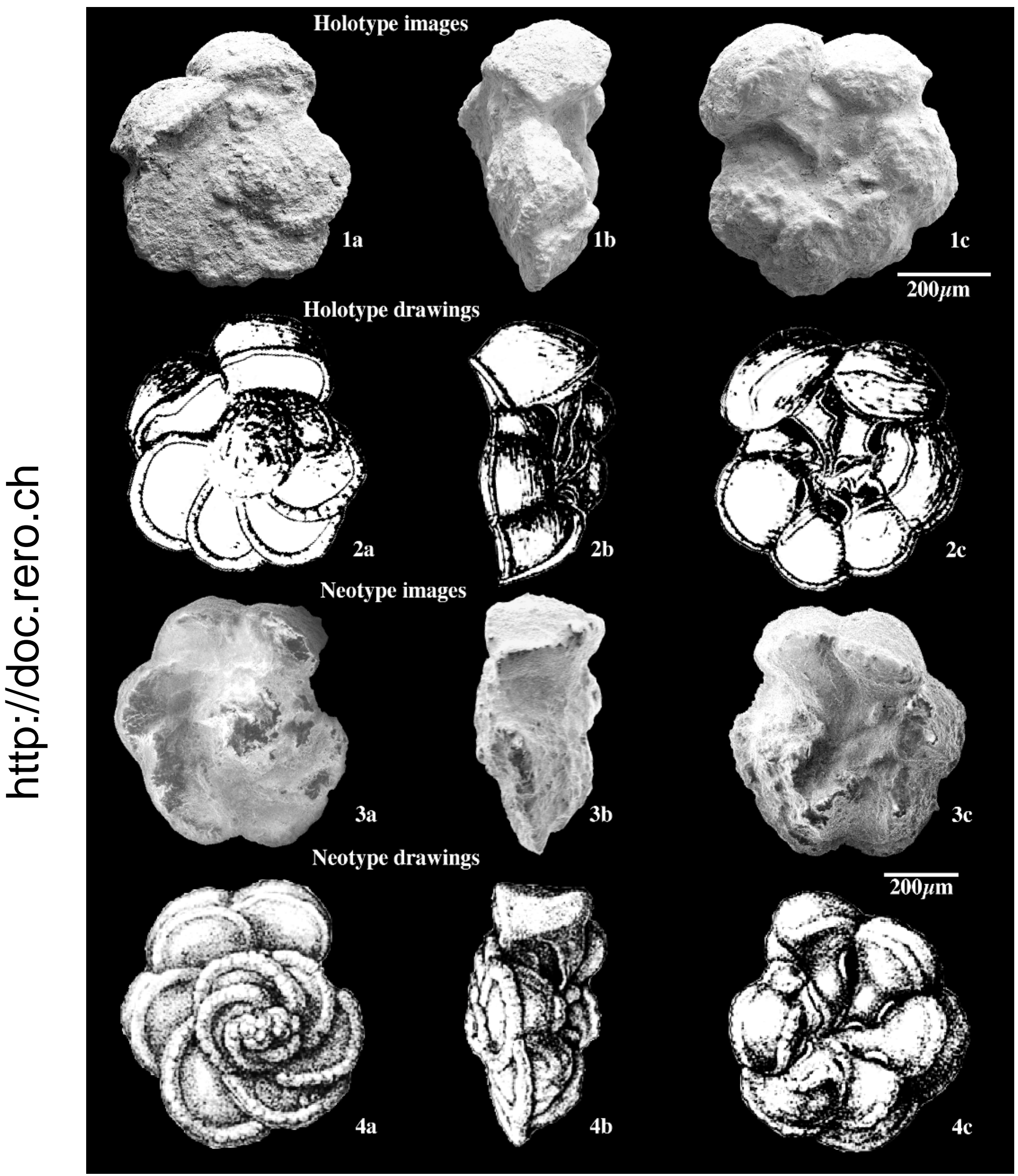

PLATE 1

Thalmanninella reicheli. 1a-c SEM images of the holotype. 2a-c Mornod (1949) drawing of the holotype. 3a-c SEM images of the neotype. 4a-c Caron (1976) drawing of the neotype. 


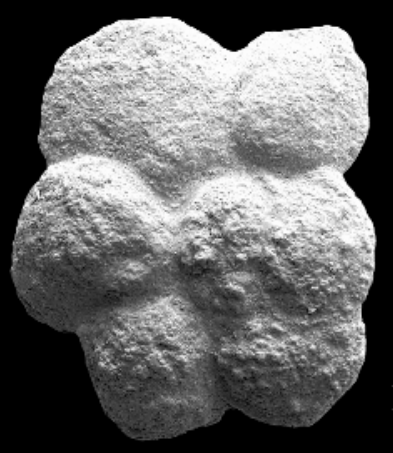

$1 \mathbf{a}$

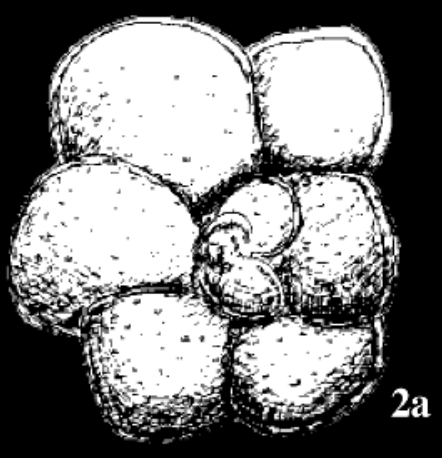

$\mathbf{a}$
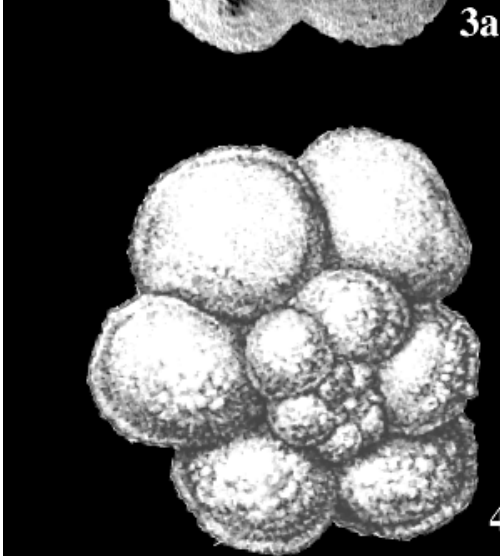

$4 a$

\section{Holotype images}

1b

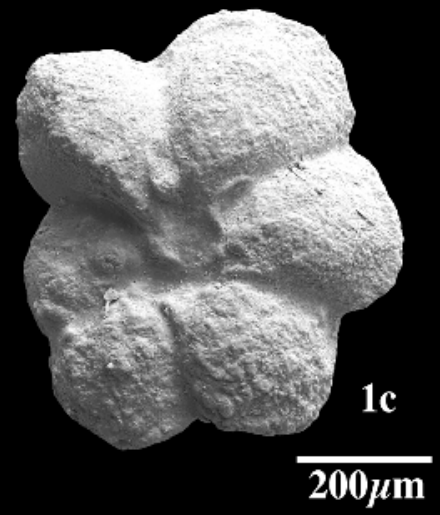

Holotype drawings
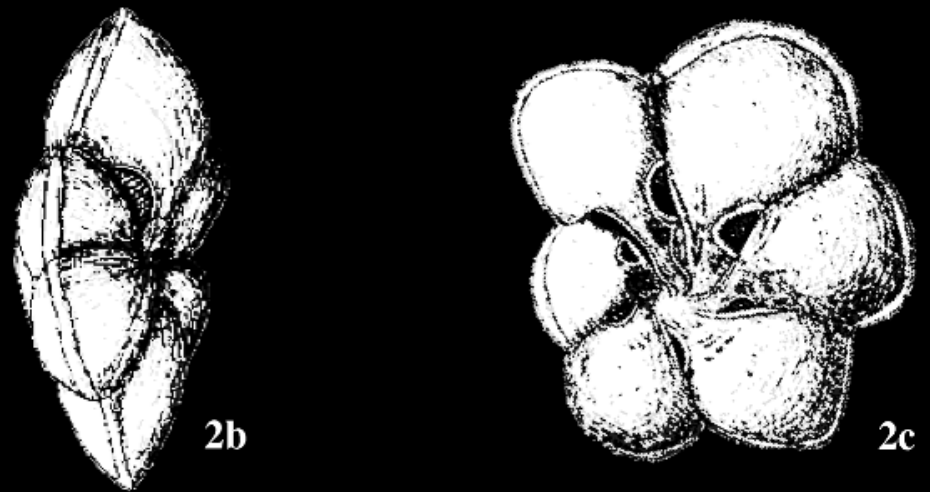

Neotype images
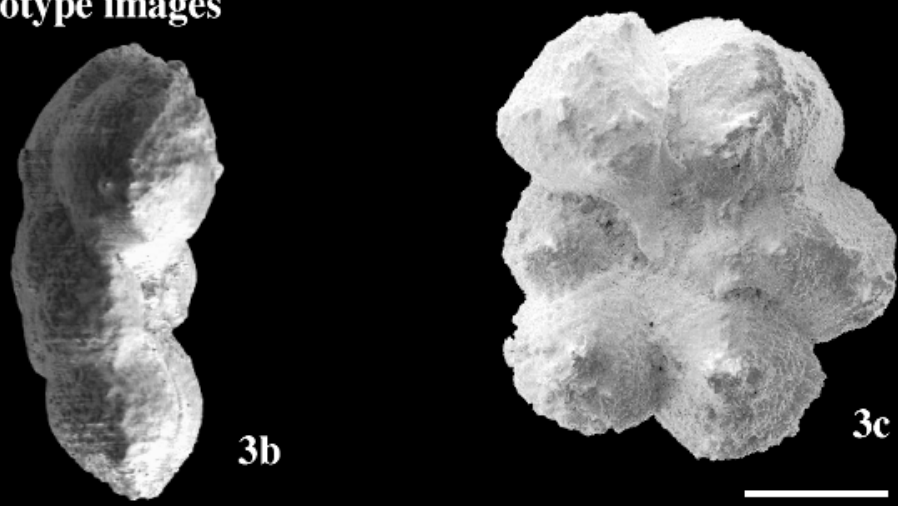

3b

Neotype drawings
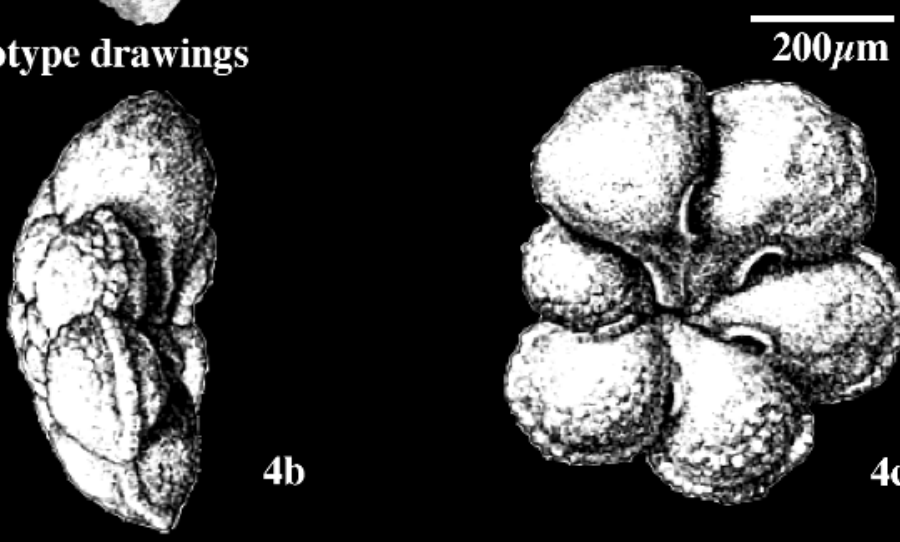

$4 b$



PLATE 2

Rotalipora montsalvensis. 1a-c SEM images of the holotype. 2a-c Mornod (1949) drawing of the holotype. 3a-c SEM images of the neotype. 4a-c Caron (1976) drawing of the neotype. 
characters: chambers are inflated and bordered by a high, welldeveloped periumbilical ridge. Sutures between chambers are depressed and bordered by a distinctly visible primary aperture (sometimes appearing as a double opening as in the holotype drawing) in the large and deep umbilical depression.

Remarks: This species is often confused with Thalmanninella micheli. Both species display a cylindrical outline, flat spiral side with inflated chambers on the umbilical side. Thalmanninella reicheli differs from $T h$ micheli in having the umbilical sutures of the first chambers of the last whorl curved, raised and connected with the peri-umbilical ridges. These ridges are absent in Th. micheli (Gonzalez-Donoso and others, in press).

The holotype is deposited at the Natural History Museum of Basel with the reference number: NMB- C39013 and the neotype: NMB33316 .

\section{Rotalipora montsalvensis (Mornod, 1949)}

Plate 2, figures 1-4

Type reference: Globotruncana (Rotalipora) montsalvensis Mornod, 1949, p. 584-585, fig. 4 (Ia-c); present article, pl. 2, figs. 1a-c, 2a-c. Neotype: Rotalipora montsalvensis Mornod; Caron, 1976, p. 329-330, text figs. 1a-c.

Topotypes: Rotalipora montsalvensis Mornod; Caron, 1976, pl. I, figs. $1-6$.

Mornod's drawings of the holotype (Plate 2, figs. 2a-c) are consistent with the SEM images (Plate 2, figs. 1a-c). A weak peripheral keel is barely visible because of the poor preservation of the specimen. The neotype (Plate 2, figs. 3a-c, 4a-c) and a large number of topotypes picked out from the reference sample (Caron 1976, Plate I, fig. 3; Robaszynski and others, 1979, Plate 15, fig. 1a-c) show the wellpreserved peripheral keel. The axial profile is biconvex with inflated chambers, and no ornamentation is present on the spiral and umbilical sides. Intercameral sutures are straight on the umbilical side, curved on the spiral side, and depressed on both sides. The supplementary apertures are distinct in the umbilical sutures, and sometimes are doubled on the last suture.

The holotype is deposited at the Natural History Museum of Basel with the reference number: NMB-C39014 and the neotype: NMB33315 .

\section{THE ACCOMPANYING ASSEMBLAGE}

The accompanying assemblage is shown in Figure 1. Thalmanninella reicheli and Rotalipora montsalvensis are well represented. Thalmanninella globotruncanoides, Th. gandolfii and Th. micheli are abundant. Transitional forms between Th. globotruncanoides and Th. greenhornensis are found, as well as rare transitional forms between Th. micheli and Th. reicheli. Praeglobotruncana stephani and P. gibba are common, representing approximately $50 \%$ of the entire assemblage. Hedbergellids are small but very abundant and well-diversified; heterohelicids are very small, generally not abundant and consist of one species Heterohelix moremani.

These assemblages have distinct stratigraphic ranges as shown by the levels marked by the dashed lines and stars in Figure 1: Star 1 corresponds to the Thalmanninella reicheli type level. This rich assemblage precedes the level with the first occurrence (FO) of Rotalipora cushmani, and it belongs to the Th. reicheli Interval Range Zone (IRZ) of the midCenomanian. Star 2, corresponds to the Rotalipora montsalvensis type level. This rich assemblage precedes the first occurrence (FO) of Th. reicheli. Neverthless, the total range of Rotalipora montsalvensis spans the broader interval from the middle part of the early Cenomanian to the late
Cenomanian (Mornod, 1949; Caron 1976; Robaszynski and others, 1979; Robaszynski and others, 1990; Premoli Silva and Verga, 2004).

\section{CONCLUSION}

The holotypes of Thalmanninella reicheli and Rotalipora montsalvensis were recently discovered and are presented here with their first SEM images. Morphological characters in the original drawings of Mornod (1949) and Caron (1976) are consistent with those represented in the SEM photographs. Despite the importance of the discovery of these previously lost holotypes, the neotypes remain good reference specimens for the two species.

\section{ACKNOWLEDGMENTS}

We warmly thank Jean Pierre Berger (University of Fribourg), who found the box with Mornod's collections and holotypes. Thanks to the members of the Mesozoic Planktonic Foraminifers Working Group and B. Huber for fruitful discussion and advice. Thanks also to Christoph Neururer for his help in SEM documentation and for the procedures for photographing neotypes without gold coating. Thanks to Brian Huber and Dick Olsson who reviewed this article.

\section{REFERENCES}

CARON, M., 1976, Révision des types de Foraminifères planctoniques décrits dans la région du Montsalvens (Préalpes fribourgeoises): Eclogae Geologicae Helvetiae, v. 69, no. 2, p. 327-333.

Gonzalez-Donoso, J. -M., Linares, D., Varon, M., and RobaZYNSKI, F. (in press). The rotaliporids, a polyphyletic group of Albian-Cenomanian planktonic foraminifers. Emendation of Genera: Journal of Foraminiferal Research.

Mornod, L., 1949, Les Globorotalidés du Crétacé supérieur du Montsalvens (Préalpes fribourgeoises): Eclogae Geologicae Helvetiae, v. 42 , no. 2 , p. 573-596.

Ogg, J., Agterberg, F. P., and Gradstein, F. M., 2004, The Cretaceous Period, in Gradstein, F. M., Ogg, J., and Smith, A. (eds.), A Geologic Time Scale: Cambridge University Press, Cambridge, UK, p. 344-383.

Premoli Silva, I., and Verga, D., 2004, Practical Manual of Cretaceous Planktonic Foraminifera, course 3, in Verga, D., and Rettori, R. (eds.), International School on Planktonic Foraminifera: Universities of Perugia and Milano, Tipografiadi di Pontefelcino, Perugia, Italy, $283 \mathrm{p}$.

RoBASZYNSKI, F., and CARON, M. (eds.), and the European Working Group on Planktonic Foraminifera, 1979, Atlas of Mid Cretaceous Planktonic Foraminifera (Boreal Sea and Tethys): Cahiers de Micropaléontologie, $366 \mathrm{p}$. -, Dupuis, C., Amédro, F., Gonzalez Donoso, J. -M., Linares, D., Hardenbol, J., Gartner, S., Calandra, F., and Deloffre, R., 1990, A tentative integrated stratigraphy in the Turonian of Central Tunisia: formations, zones and sequence stratigraphy in the Kalaat Senan area: Bulletin Centres Recherche et Exploration-Production Elf-Aquitaine, Boussens, v. 14, p. 213-384. 